\title{
Studying The Selection of The Priority Industry And Lessons Learned for Local And Excessive Thai Nguyen
}

\section{ThS. NCS Nguyễn Thị Hằng}

Faculty of Economic Information System - Information and Communication Technology Thai Nguyen University, nthang@ictu.edu.vn

\begin{abstract}
From the development reality of each country, each locality, due to its limited and scarce resources, can not simultaneously develop its branches and technical fields. Industry priority to develop in the most effective way, in accordance with the international context of each stage. To create a momentum for accelerating industrial development in the short term, it is necessary to identify and narrow down the scope of priority industries to focus on development, to avoid widespread investment. not tall. To develop priority industries in order to make optimal use of local comparative advantages, creating a spillover for the development of the entire industry.

Keywords: Industry, Job Priority, Leadership, Supporting Company, first development for development.
\end{abstract}

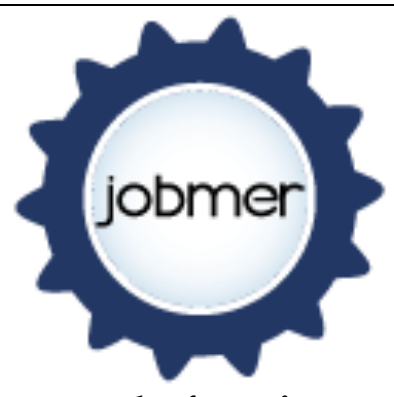

Journal of Business

Management and Economic Research

Vol.2, Issue.2, 2018

pp. $1 \mathrm{~m} \quad 6$

Doi: 10.29226/TR1001.2018.17 


\section{Introduction}

Industry is the main economic sector of the economy, industrial development is the indispensable task for successful implementation of industrialization and modernization of the country. The goal of our country is to strive to become an industrialized country in the modern direction. In order to achieve that goal, we need the continuous effort of all sectors of industry. However, it is not possible at the same time to develop all sectors of the industry effectively, which need to be selected, prioritized for development. They have to be the leader, have the strength and create the competitive edge to use the country's finite resources.

\section{Theoretical bases for selection of priority industries}

The choice and development of priority industries are in industrial policy. Industrial policy is defined as all policies that support the production and development of industries within a country. When policy makers weigh the question of what industrial policy is good for growth and development, to simplify this discussion, two types of solutions are often proposed. This is the result of the study of the topic at the level code T2018-07-04.

It can be said that the development of priority industries is a popular tool for implementing industrial policy. The development of priority industries to change the production structure of the priority industries. These are the basic, spherical and advantageous sectors of development. In the speech "Identifying Preferred Industries in National Industrial Policy" by author Vu Thanh Tu Anh, Fulbright University: The author has given some international experience of Japan, Korea, Taiwan on priority industrial development. The author argues that Vietnam should not pursue preferential policies for some specific industrial products. Instead, the Government should implement a policy of prioritizing the development of a number of "capacity areas" in line with the country's long-term development goals and strategies.The experience of countries in the world with many successes such as Japan, Korea, Taiwan (China), Thailand show that their industrial development process is in stages, The industry has a competitive advantage, in that precision engineering plays an important role in all industries. Based on analysis and comparison of development conditions across countries, the author mentions a number of principles for selecting priority industries for Vietnam based on 12 basic principles such as comparative advantage comparative, spillover effect, high growth rate, etc. The development of priority sectors for the development of priority industries is appropriate. the industry is strong, so that the nucleus pulls the development of other industries.

\section{Experiences of some localities in the selection and development of priority industries}

\section{Experiences of Binh Duong}

Binh Duong is an industrial province which has high growth rate and high contribution in GDP. In 2016, the industry accounted for over $63 \%$ of the total economy. For the whole country, the industry contributes more than $10 \%$ of production value and accounts for $11 \%$ to $12 \%$ of export turnover (2016). In the process of economic development, Binh Duong is always interested in developing priority industries because it is a breakthrough for the province to develop rapidly and sustainably in the process of industrialization. Therefore, Binh Duong has implemented the development of priority industries. The province strives to become one of the major centers of the country in terms of producing industrial products to support the textile and garment and footwear industries and achieve high competitiveness in the region by 2020. In addition, the fields of pharmaceutical, electronics, telecommunication, informatics and mechanical engineering will become the main growth drivers of the industry and contribute significantly to the province's export turnover in the period. 2010 - 2020 period. 
Corresponding to each stage, in order to be suitable with local development conditions, the province has developed appropriate priority industries. In the period of 2008 - 2010, the province has prioritized the development of major industries such as textile and garment supporting industries; supporting industry of leather and footwear industry; agricultural, forestry and food processing; chemical industry, rubber (basic chemicals, pharmaceutical chemistry, cosmetics, natural rubber products). In the period of 2011 - 2015, the province has prioritized the development of supporting industries in the textile and garment industry; supporting industries in the footwear and footwear industries, agro-food processing industry; chemical industry, rubber (basic chemicals, pharmaceutical chemistry, cosmetics, natural rubber products). In the 2016-2020 period, the province shall prioritize the development of supporting industries in the textile and garment industry; supporting industry of leather and footwear industry; chemical industry (pharmaceutical chemistry).

\section{Experience of Dong Nai}

Dong Nai is one of the three corners of the southern development triangle, including Ho Chi Minh City - Binh Duong - Dong Nai, with a strong industrial development in the south. In the period of 2006 - 2015, the province has shifted to develop the industry in parallel with the strategy of sustainable development, the industrial growth rate is $13-14 \%$ per year. Thanks to investment in the right direction, priority is given to the development of key industries with comparative advantages, which make up a significant contribution to the economy of the province. In the process of development, Dong Nai prioritizes the development of hi-tech industries, the production of accessories and auxiliary materials for import substitutes, and the processing of agricultural products and foodstuffs. At the same time, the province encourages labor-intensive industries in rural, remote and isolated areas; Transferring some industries from the form of processing to the production of finished products, direct export to increase the value. To restructure the industry with the priority of attracting investment in hi-tech industries and supporting industries; Applying technology to save raw materials, fuel, materials and energy. To concentrate on intensive investment in developing high-quality and competitive industries. From 38 factories operating in Bien Hoa Industrial Zone (now Bien Hoa Industrial Zone I), after the liberation of the South, the province has 13,700 industrial establishments operating by 2015, including : 40 state enterprises (Central 32, local 14); 12,940 non-state owned enterprises, 725 foreign-invested enterprises. The industrial production value in 2014 has increased 200 times compared to 1986. Over 30 years of construction and development, Dong Nai industry has grown in both quantity and quality and is moving rapidly into the field. high technology, supporting industries, high value added under the green growth strategy and sustainable. Up to now, the share of industry accounts for over $57 \%$ of GDP, playing an important role in the annual economic growth of the province.

\section{Experience of Bac Ninh}

Bac Ninh is considered as a dynamic and modern industrial city in the northern part of Vietnam. Bac Ninh and Thai Nguyen are currently attracting large FDI projects, bringing about a breakthrough in industrial development. Significant development of high technology industry of Samsung Group - Korea in both provinces. In the last 5 years, Samsung Bac Ninh and Samsung Thai Nguyen have many relationships in the common use of labor resources, electronic manufacturing infrastructure. The province has set the target of striving to become a centrally-run city in the 20's of the 21st century towards civilization and modernity. In the 20162020 period, the total output of the province will reach $10.5 \%-11.5 \%$ / year, of which industry and construction will increase by $11.3 \%-12.6 \%$. In the period $2021-2030$ : industry and construction increased by $6.8 \%$ on average. To contribute to the economic restructuring in the direction of industrialization and modernization and trade in services of high level and quality. 
Industries that are prioritized by the province include: Manufacturing of components and electronic equipment; Components and electrical equipment will prioritize the production of electronic products for industry, electronics, telecommunication, computer brands of Vietnam, mobile phones, electronic components for production and export; It can also be used in rural areas (through industrial promotion programs and supporting industry development programs). Machinery, equipment and metal processing industries are concentrated in manufacturing molds for the electrical, electronics and automobile industries; motorbike; dynamo; Agricultural Machinery; Machines used in the agricultural, forestry and fishery processing industry; Rapid development of the software manufacturing industry. This is one of the areas with the highest levels of gray matter, creating great added value and not consuming resources, energy or polluting the environment. In addition, Bac Ninh also develops pharmaceutical, pharmaceutical and hi-tech industries such as nanotechnology, biotechnology and agro-forestry-fishery processing. To serve the export and domestic consumption, especially for the Capital Region and export with the quality of international standards to target Japan, the US, the EU, ASEAN and some markets. other. Major industrial products will be prioritized for development, including: electric and electronic products; Precision mechanical products: mold, molding, plastic injection, metal punching; Pharmaceutical and pharmaceutical products; Products processing agricultural and forest products, food. Thus, from a pure agricultural province, Bac Ninh has emerged as an industrial province and attracted investment from large corporations such as Samsung, Microsoft, Canon, Pepsico and became a dynamic industrial province. the country in recent years.

\section{Lessons Learned for Thai Nguyen in Choosing Priority Industries}

Thai Nguyen is a province in the Northern Midland and Mountain area with potential and strength in natural resources and has a long tradition in industrial development. In the past years, especially since the re-establishment of Thai Nguyen province (1997), the provincial leaders have grasped the opportunities, put forth guidelines and policies for socio-economic development, industrial development right there have been some successes in economic development. The economic structure of Thai Nguyen province has been shifted positively towards the gradual increase of the Gross Domestic Product Product (GRDP). In the general economic structure, industry plays an extremely important role, contributing significantly to changing economic structure of the province. The development of Thai Nguyen industry in recent years has achieved positive results and is highly appreciated. However, to date, the development industry has not matched the scale and available resources, low business efficiency, Thai Nguyen is still one of the poor provinces, some socio-economic indicators. lower than the national average. A number of well-known enterprises, which were the driving force behind the economic development of the whole province, also fell into recession, leading to the bankruptcy of Thai Nguyen Iron and Steel. Industrial enterprises are heavily dependent on foreign direct investment and there is no strong integration to create breakthrough developments, moving from satellite enterprises to integrating deeper into the supply chain. global response. Therefore, in the industrial development strategy, the province has focused on developing a number of areas, emphasizing investment in supporting industries.

Supporting industries in Thai Nguyen have been developed since 2005 to promote the advantages of an industrial province. In 2017, the whole province has 209 supporting industries. Among them, the number of FDI enterprises producing electronic components accounted for the largest number with about 50 enterprises; followed by the production of metal products, the production of ball mill products, steel pipes, cast iron, casting parts of cars, gearboxes. The average annual growth rate of the supporting industry is 59\%, accounting for nearly $40 \%$ of the province's industrial production value. Manufacturers of supporting industry products can 
meet the demand for various industries and directly serve the enterprises manufacturing products in the integrated way from the beginning to the end. Typically like: Machinery Parts Joint Stock Company No. 1, Diepel Song Cong, Narime Machinery and Equipment Manufacturing Joint Stock Company manufacturing mechanical products and integrated industrial equipment ... From 2013, many foreign enterprises has invested in support projects for Samsung Group. Notable among them are Dong Yeon Industrial Co., Ltd. (Korea), which manufactures monitors, boards, memory card slots on mobile phones; Bujeon Electronics (Korea) Co., Ltd with electronics factory Glonics Vietnam specializes in producing headphones for mobile phone manufacturers (typically Samsung); Alutec Vina Co., Ltd. (Korea) with factory specializing in manufacturing, processing products from aluminum supporting the field of construction and manufacturing of mobile ...

The products of the supporting industries in Thai Nguyen include diesel engines, gearboxes, motorcycle parts, construction products, electronics industries, etc. Labor force operating in the industry accounting for $32.5 \%$ of industrial workers in the province (2017). In terms of quality, the labor force operating in the sector is judged to have a higher level of professional qualifications than other industries, because the characteristics of the SI require workers to be modernized., specialization and high co-operation. The number of trained workers in this sector accounts for over $90 \%$ and has partly met the production requirements of enterprises. In terms of technology level, only 02 enterprises are operating in hi-tech industry. Currently, Thai Nguyen has more than 1,000 individual households involved in the production of SI products, however, the size of the households is very small, each household has an average of 2 laborers, mainly producing steel fabrication work. Construction, machinery, equipment, tools, small tools, semi-craft to serve the needs of the local.

At present, most of supporting enterprises in Thai Nguyen are only supporting satellite for big companies such as Samsung - Korea, Toshiba, ... but not deeply integrated into the supply chain of supporting products. for large FDI partners to form a network in the global value chain. In 2018, a number of supporting companies such as Disoco will complete technology investments to meet the standards and meet the conditions required to join the global supply chain of major manufacturers in the world. Thanks to the large Samsung projects that are operating effectively in Thai Nguyen, there will be more opportunities for the province to attract Korean businesses to cooperate with local businesses to transfer SI technology. This will help local businesses gain access to new technologies to produce, upgrade their skills, and enable them to stand alone to produce SI to supply large production chains such as Samsung.

\section{Conclusion}

Prioritized industrial development is a right policy of the country and localities to focus resources to prioritize development in a selective way. Therefore, the first task is to identify the priority group of companies depending on each stage, each period of development. Such industries must be spearheaded by other sectors in order to exploit the inherent comparative advantages of the locality in order to bring into full play their comparative advantage, mobilize and efficiently use resources., enhance competitiveness, promote economic restructuring in the direction of modern. On the basis of the selection of priority industries in a timely manner with the intervention of preferential policies will create the motivation to promote the development of the entire industry. This research will support a great deal in clarifying the research that T2018-07-04 is about. 


\section{REFERENCES}

The Central Economic Committee, Ministry of Industry and Trade (2017), "International Scientific Conference "Vietnam's National Industrial Policy till 2025 with vision to 2035", Hanoi.

Pham Thi Huyen (2011), Policy on the development of industrial clusters in Korea, Proceedings of the seminar on economic development cooperation between Vietnam and Korea, National Economics University Publishing House, Hanoi.

Kenichi Ohno (2004), Industrial Policy Formulation in Thailand, Malaysia and Japan: Lessons for Vietnamese Policymakers, Political Theory Publisher, Hanoi.

Kazushi Ohkawa and Hirohisa Kohama (2004), Japan's Industrialization Experience and its Relevance to Developing Economies, Social Science Publishing House, Hanoi.

Dinh Vu Trang Ngan (2011), Industrial Policy, Fulbright Economics Teaching Program

Bui Tat Thang (1998), "Approaching the Study of the Process of Industrialization", Journal of Economic Research, (8), pp. 9-16. 